\title{
IMPACT OF COASTAL INUNDATION ON ECOLOGY AND AGRICULTURAL LAND USE CASE STUDY IN CENTRAL JAVA, INDONESIA
}

\author{
MuH ARIS Marfai \\ Faculty of Geography, Gadjah Mada University, Yogyakarta, Indonesia
}

Manuscript received: July 13, 2011

Revised version: September 5, 2011

\begin{abstract}
MARFAI M.A., 2011. Impact of coastal inundation on ecology and agricultural land use case study in central Java, Indonesia. Quaestiones Geographicae 30(3), Bogucki Wydawnictwo Naukowe, Poznań, pp. 19-32, 22 Figs., 4 Tabs. ISBN 978-83-62662-75-3. ISSN 0137-477X. DOI 10.2478/v10117-011-0024-y

AвSTRACT: Focusing on the regional scale, this study provides information concerning the existing ecological problems associated with coastal inundation in the northern part of coastal area in Central Java Province, Indonesia. The objectives of this paper are to map the coastal inundation, to investigate the impact of coastal inundation on coastal environment and ecology, and to assess the impact of inundation on agricultural land use. An integration of techniques, namely neighborhood analysis, iteration operation, and superimposed analysis method has been applied to generate the digital map and to analyze the impact of inundation. Fieldwork measurement has been done using cross-profiling in order to observe the impact of inundation on the coastal ecosystem. Based on the scenario of $100 \mathrm{~cm}$ and $150 \mathrm{~cm}$ of inundation, the affected area is about $15207.6 \mathrm{Ha}$ and $16687.31 \mathrm{Ha}$, respectively. Fishpond, dry farming and paddy field are the most affected agricultural areas due to coastal inundation.
\end{abstract}

KEYwORDS: Coastal inundation, ecology and agricultural impact, GIS technology, Central Java, Indonesia

Muh Aris Marfai, Faculty of Geography, Gadjah Mada University, Yogyakarta 55281 Indonesia, e-mail:arismarfai@gadjahmada.edu / arismarfai@yahoo.com

\section{Background}

Indonesian coastal area, with a total coastline of more than $80000 \mathrm{~km}$, is facing environmental problems and vulnerability due to coastal multiuse purposes and lack of appropriate land use management (Marfai \& King 2008a). The most serious environmental problems are inundation and displacement of wetlands and lowlands, increased coastal storm flooding, as well as increased salinity of estuaries and aquifers. Coastal area of the northern part of Central Java Province has been rapidly developed for multi-use purposes i.e., economic, trading and industrial development, agricultural activities, tourism and settlement area.

Coastal area of Central Java Province, geomorphologically speaking, stretches for miles of coastline, covering the cities of Kendal, Semarang, Demak and Jepara, and consists of mud flat and sandy beach with an elevation of less than $5 \mathrm{~m}$. Geomorphological processes occur on the lowland area, including erosion- sedimentation, land subsidence and tidal inundation. Marfai et al. (2008) investigated the shoreline dynamic on the local area of the Semarang City. During the period of almost 100 years, from 1908-2003, the shoreline dynamic in Semarang coastal area was 
dominated by sedimentation process. Shoreline extended to the sea as a result of man-made infrastructure and natural processes. In addition, Maulina (2010) has investigated the shoreline dynamic in Demak coastal area, Central Java Indonesia using landsat remote sensing data. Using the combination of the pixel-based and objectbased methods, her research revealed that some major areas in Demak's coastal area had experienced both abrasion and accretion intensively. The shoreline change also brings some significantly negative impact to the coastal community livelihood.

Meanwhile, land subsidence in part of coastal area of Central Java Province generally occurs due to the groundwater withdrawal as well as natural consolidation of alluvium soil and subsidence induced by the load of construction (PWD, 2000, Marfai \& King 2007). High rate of subsidence up to more than $10 \mathrm{~cm}$ per year is occurring in several spots of Semarang low lying area. Marfai \& King (2007) have introduced the subsidence model based on raster GIS which later on revealed that about $27.5 \mathrm{Ha}$ land on the coastal area would sink in 2020 and the ground elevation would be about $1.5 \mathrm{~m}$ to $2.0 \mathrm{~m}$ below sea level. Increasing subsidence on the coastal area was also predicted to increase the inundation due to tidal process.

Tidal inundation due to sea level rise is a major issue for the local government along the coastal area of Central Java Province. The inundation has a tremendous impact not only on the people and infrastructure but also on agricultural activities. Damage and loss of agricultural production from coastal inundation is enormous. Marfai \& King (2008b) have conducted preliminary research of the impact assessment of the inundation under the scenario of sea level rise due to climate change on the local scale of Semarang coastal area. Marfai \& King (2008b) revealed that the coastal land use was facing inundation in different levels of vulnerability. Marfai \& King (2008b) have also addressed the rough calculation of the monetary losses analysis due to the inundation. However, agricultural land use assessment, including coastal aquatic cultivation in wider areas such as in Kendal-Semarang-Demak-Jepara coastal areas, has not yet been done.

From the agricultural point of view, the areas mostly affected by coastal inundation are fish- pond area, rice fields, and mix crop dry cultivations. Coastal inundation may cause damage to the plant, loss of fishes on the fishpond area, degradation of water quality and quantity -particularly groundwater-, and also increase plant disease. Data acquired by applying remote sensing technique for assessment of agricultural crops become an increasingly important source of information on agricultural land use management. Assessment of the agricultural flood damage using Landsat imagery has been done by Johannsen et al. (2007). Focusing on the assessment of the impact of inundation on agricultural land use, Michele (1999) has introduced a geomorphological and ecological approach to integrated modeling of coastal land use change. Moreover, along with socio-economic impact, environmental impacts of inundations are of special interest. The environmental impact of inundation involves changes in the water quality, disturbance of vegetation and agricultural land use (Lebedeva et al. 2005). In addition, Schladow et al. (2005) have introduced a simulation of inundation impact and habitat extent for a tidal freshwater marsh restoration. In wetlands, the dynamics of inundation have proved to determine the interdependence between hydrological and biological processes and exchanges determining the composition and distribution of vegetation (Pasternack et al. 2000).

Since the high potential natural resources in the coastal area might be threatened by inundation, it is important to know the spreading area of inundation, observe the environmental problem related to the coastal inundation, and assess their impact on ecology and agricultural land use. Initial project of inundation mapping on the northern part of Semarang urban coastal area has been carried out by Marfai \& King (2008c). This paper intends to map the inundation in the wider area of Kendal-Semarang-Demak-Jepara coastal areas. Figure 1 shows the study area and area of the previous research by Marfai \& King (2008c). This study has also provided valuable data and information concerning damage on ecology and agricultural land use which serve as aid in planning a set of programs to deal with coastal zone management. 


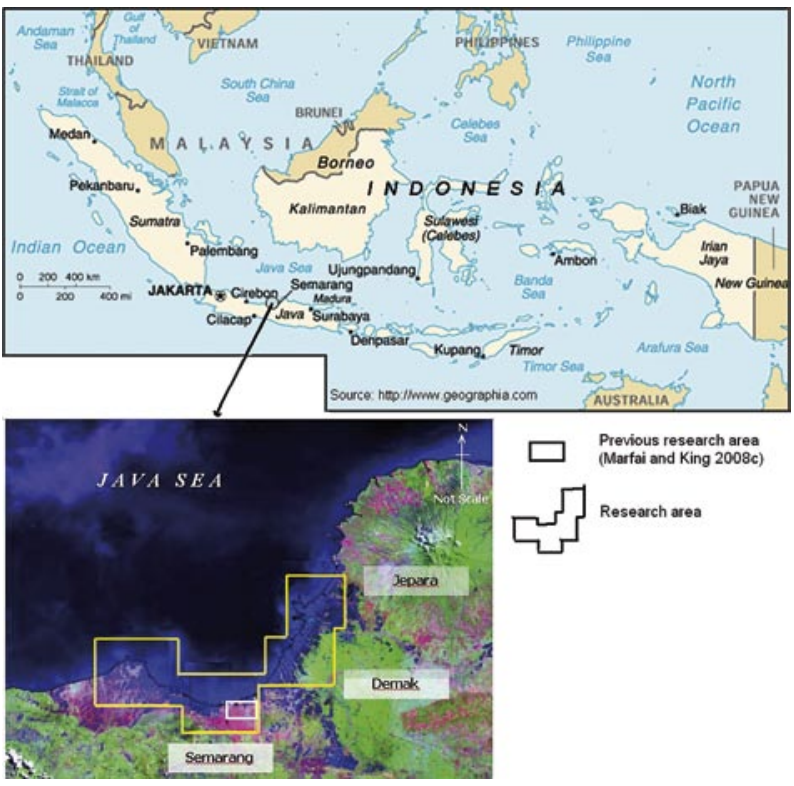

Fig. 1. Research area.

\section{Objective}

The objectives of the research are:

1. To generate coastal inundation map in Central Java coastal area.

2. To investigate the impact of inundation on coastal environment and ecology.

3. To assess the impact of inundation on agricultural land use.

\section{Methodology}

Comprehensive assessment and understanding of the consequence of flood spreading on the coastal area can be done by utilizing a spatial modeling. The Geographic Information System (GIS) technology provides tools for modeling and assessing the hazard processes, as it is also increasingly being applied on coastal inundation mapping, for instance by Kresch et al. (2002), Kumar Dinesh (2006), Marfai \& King (2008b, 2008c), Ward et al. (2011). Following the growing availability of Geographic Information System (GIS) for hazard mapping and modeling, a scheme to map the inundation using raster-GIS and its impact including agricultural land use assessment is proposed on this current project.

The research has been divided into three technical tasks to achieve the objectives of the research. The technical tasks are: 1) Conducting spatial analysis using the state of the art of GIS technology,-neighborhood analysis and iteration operation in ILWIS software-, for inundation map development, 2) Conducting cross-profile and rapid observation during field measurement to identify the ecological damage due to inundation, 3) Conducting GIS-superimpose technique between coastal land use map and inundation model in order to assess the impact of agricultural land use due on inundation.

\section{Coastal inundation map development}

Data related to land surface elevations is urgently needed prior to the assessment of the impact of coastal inundation. In the iteration operation system using raster-GIS environment, the digital elevation model (DEM), -which is containing information on land surface elevation-, is the basic data to generate the inundation map. A DEM data of the study area was generated based on the contour map using moving average point interpolation method in GIS-raster environment. The contour map from the Topographic map scale 1:25.000 has been used to create the whole DEM of the study area. Since part of the study area, in this case the Semarang and Demak coastal areas, experiences subsidence phenomenon, the DEM data should be updated with regard to the rate of the subsidence. Marfai \& King (2007) have updated the DEM data of the part of the study area. This updating process is based on the calculation of the additional control points by field measurement using geodetic and differential global positioning system (DGPS) equipment conducted by Sutanta (2002). This detailed DEM of the Semarang area has been integrated with the DEM data of the rest of the study area.

The magnitude of inundation is usually associated with a number of different parameters, such as depth of water and duration. Single parameter of the depth of water is chosen in this research to determine the inundation model. Inundation spreading map has been developed using spatial analysis tool i.e., iteration operation in GIS ILWIS software. This operation is performed as iterative calculation on the pixels in raster map system. Iteration operation as guided in ILWIS software (ILWIS 2000), is a mathematical operation 
by repeated calculations on the neighbor pixels in raster map. Once the calculation is performed, the result is used as input for the next calculation, so on and so forth until the last pixel on the map. In ILWIS (2000), the iterative operation has been illustrated as in the formula 1.

Iteration result $=$ MapIterProp (startmap, iterexpr, nr of iterations)

Where: Iteration result is the output map in a raster format. MapIterProp is the expression, which defines the calculation to be performed. Startmap is the input data, which contains one or more pixels acting as the starting point for the calculation. Iterexpr is the iteration-expression, which defines the calculation to be performed, and $\mathrm{nr}$ of iterations is the number of iterations to be performed.

\section{Identification of the ecological and environmental damage due to inundation}

This research has applied the cross profile and field rapid observation to investigate the impact of inundation on coastal environment and ecology. Topographic map, DEM data, coastal geomorphological unit are factors to be considered for profiling and field orientation. Physical and ecological conditions as well as the environmental damages due to the inundation are the main focuses to be observed during the cross profiling and fieldwork activity. In addition, geo-ecological units, which comprise coastal geomorphological characteristics (landform) and ecological units (landuse), have been used as a basis unit for the field observation. Topographic map has also been used to delineate the research boundary and to design field route and mapping.

\section{Assessment of the inundation impact on agricultural land use}

Assessment of the impact of inundation on agricultural land use requires an agricultural land use map. Visual interpretation of Ikonos image has been done to identify land use units, including mix crop cultivation, aquaculture/fishpond, paddy field, etc. Ikonos has a high resolution from 1 to $4 \mathrm{~m}$, allowing better image capturing which is very valuable for detailed coastal land use mapping. The landuse map has been generated using visual interpretation technique in combination with the spectral analysis of images and field observation. Satellite data has been registered in Universal Transverse Mercator System (UTM) with the WGS 84 spheroid.

Agriculture and plantation production, including paddy, dry farming, and other agricultural vegetables, as well as the aquatic industry such as fishpond cultivation, are the most important economic activities for the local community along the coastal area of Java. The inundation would impact on the agricultural cultivation, fish production and also bring about disturbance on the ecosystem of water environment. To calculate the impact of the inundation on agricultural landuse, superimposed method in GIS raster environment between agricultural landuse map and flood hazard map was applied.

\section{Result and Discussion}

\section{Coastal Inundation Mapping}

According to Smith \& Ward (1998), coastal tidal inundation is defined as flood in low-lying coastal areas caused by high tide, including estuaries and deltas, involving inundation of land by brackish or saline water. Study pertaining to coastal flood assessment in Central Java has received little attention, the few available reports include those of Kobayashi (2003) and Marfai \& King (2008b). Several previous studies mostly deal with the river flood phenomena (Yusuf 1999, Sudaryatno 2000, Gatot et al. 2001 and Pinem 2002).

In order to understand the spatial distribution of the inundation and its impact on the coastal area of Central Java, a map of the inundated area as a result of high water level is undeniably required. For this purpose, geoinformation technology, such as digital elevation model (DEM), neighborhood analysis, and other facilities in raster-GIS technique has the advantage to model the spatial spreading of the inundation. Using various methods, some researchers such as Thumerer et al. (2000), Bryan, et al. (2001) Marfai (2004), Marfai (2005), Marfai \& King (2008b) 


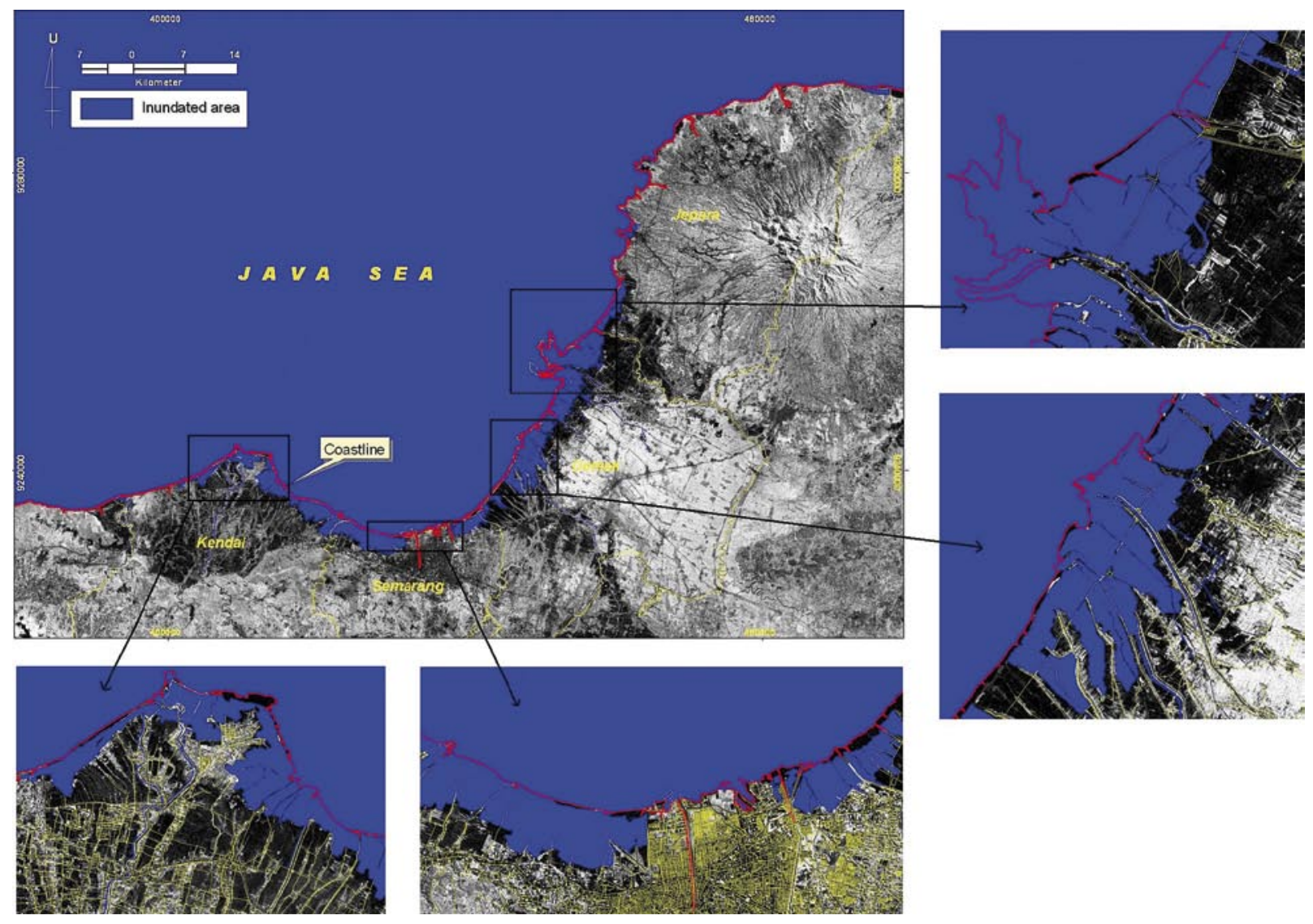

Fig. 2. Coastal flooding with scenario of $100 \mathrm{~cm}$ inundation.

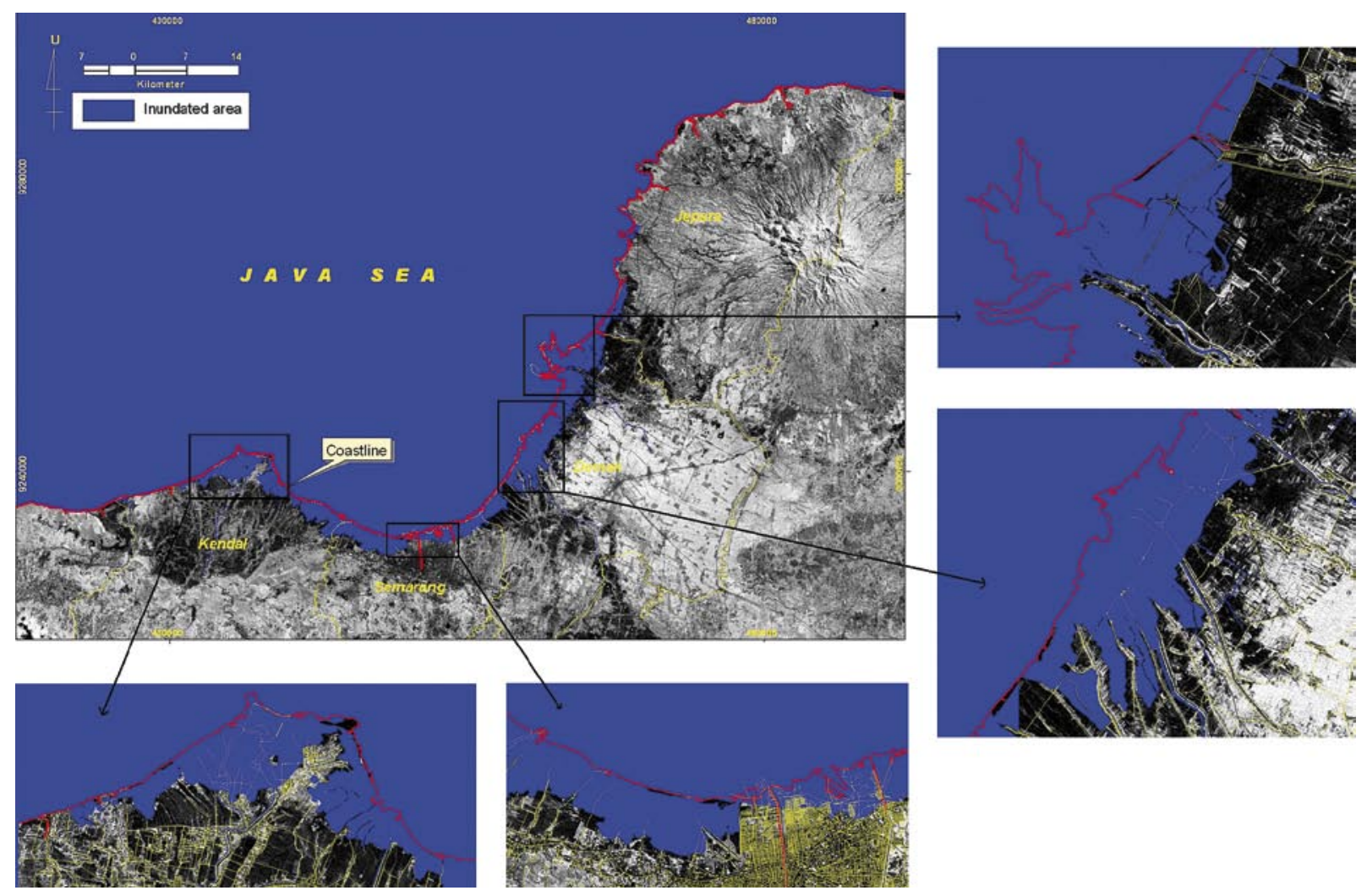

Fig. 3. Coastal flooding with scenario of $150 \mathrm{~cm}$ inundation. 
have developed the inundation mapping and modeling by taking advantage of the state of the art GIS technology. In this study, coastal inundation mapping has been constructed based on the scenario of water depth and DEM data using iteration in GIS-raster environment. According to Marfai \& King (2008b), inundation modeling using iteration operation is recognized as a realistic model considering the characteristic of the tidal spreading process. Every inundated area on the map has a path and pixels which are connected to each other. Therefore, this method is considered as an advantage technique on the geo-information technology employed to determine the spreading area of tidal inundation.

The inundation has been mapped using different scenarios of water depth. On this mapping, only one single factor, i.e., depth of inundation is considered. Other environmental factors such as coastal sedimentation, erosion, land subsidence, drainage system, etc are not taken into account. However, incorporatingt several environmental factors above would be exceedingly complex for modeling. Therefore, simplification has been made on this mapping by using two different scenarios of water depth, i.e., $100 \mathrm{~cm}$ and $150 \mathrm{~cm}$ depth of water, as those cases are the worst inundation scenario mentioned by the local community. The inundation pattern of the study area for $100 \mathrm{~cm}$ and $150 \mathrm{~cm}$ are presented in Figure 2 and 3, respectively.

\section{Preliminary assessment of the impact of inundation to environment and ecology}

Cross profiling has been designed for 8 transect routes representing entire research areas (Figure 4). During the investigation, meticulous assessment and observation in each geo-ecological unit was carried out. Information from local community and key persons (head of village) during the profiling and interview activity were very valuable in order to get a description of the ecological and environmental problem associated with inundation.

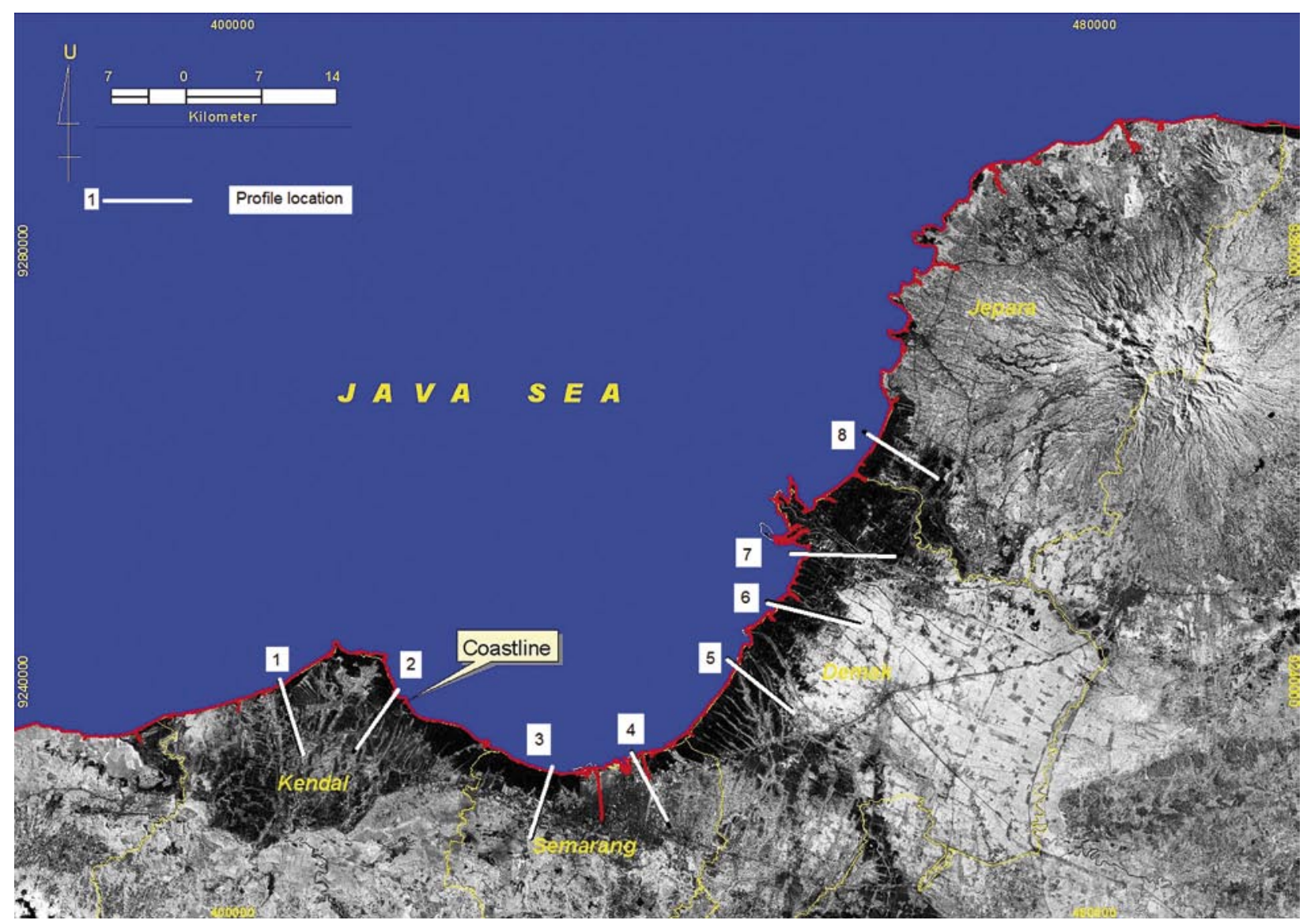

Fig. 4. Cross profile location. 


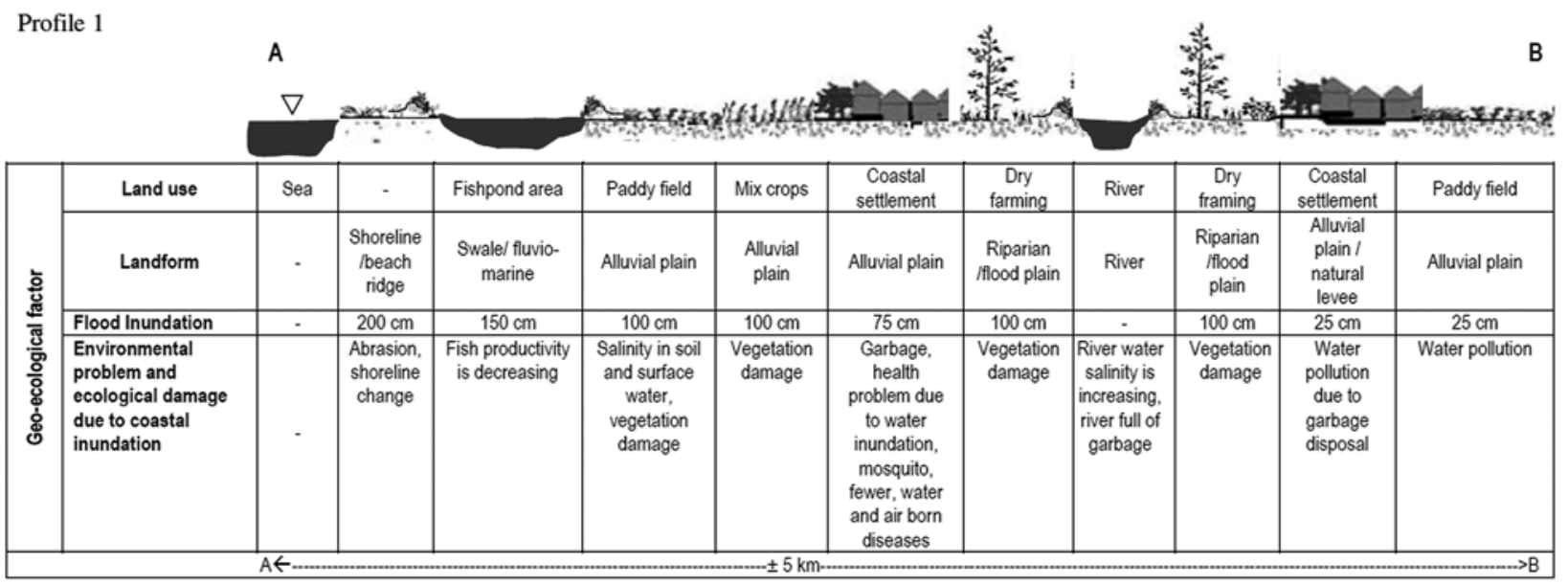

Fig. 5. $1^{\text {st }}$ cross profile.

Cross profile 1 (Figure 5) reveals that inundation due to tidal process has impact on the productivity of the fish cultivation on the fishpond area. On this first profile, the geo-ecological units consist of 6 landforms. Coastal settlement has been inundated and causes environmental problem since the water cannot be drained immediately after the inundation. Water remains on the yard and event in houses, leading to the environmental health problem such as water born diseases. This phenomenon particularly happens on the slump area or low income settlement area, where there was insufficient number of drainage system to drain the tidal water. The environment condition is even worse since the settlement has no sufficient sewage and disposal system. Garbage and disposal are transferred by water to the yard and houses (Figure 6). These conditions can attract mosquitoes and create fever. Moreover, Garbage and disposal found in the environment of coastal settlement will generate water and air diseases. Sea water inundation causes vegetation damage, particularly on the mixed crop cultivation and paddy field. Paddy and crops are damaged due to the inundation (Figure 7) and salinity of the surface water and soil is increasing after the inundation. Continuous inundation of paddy and crops fields can result in deterioration of root system. Even though paddy field is wet farming, continuous and longer inundated water on paddy field will effect decomposition of the plant. Higher water inundation to these fields can make the farmer lose his yield during harvest season.

The second transect has the same horizontal distant as the first one (Figure 8). A 100 centim- eters high of water inundation in this area can decline productivity of fishpond. Fish with various sizes and heterogeneous age can be carried away by water flow from inundation water. Continuous inundation occurrence threatens to bring loss of fishpond area in coastal area (see example

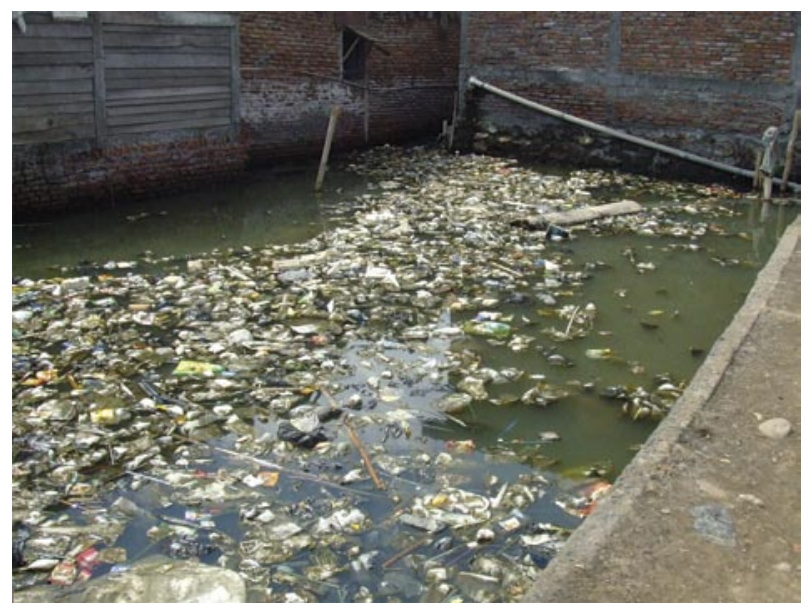

Fig. 6. Garbage and waste disposal problem in coastal area.

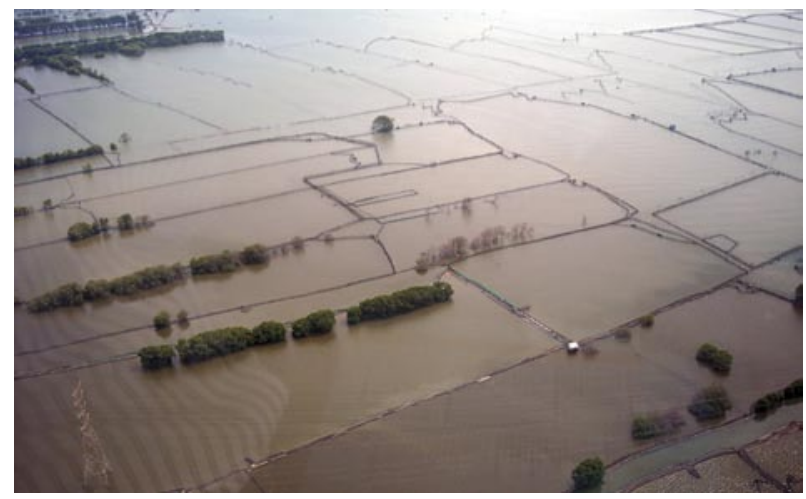

Fig. 7. Inundated paddy and crops (Photo courtesy: Helmi). 


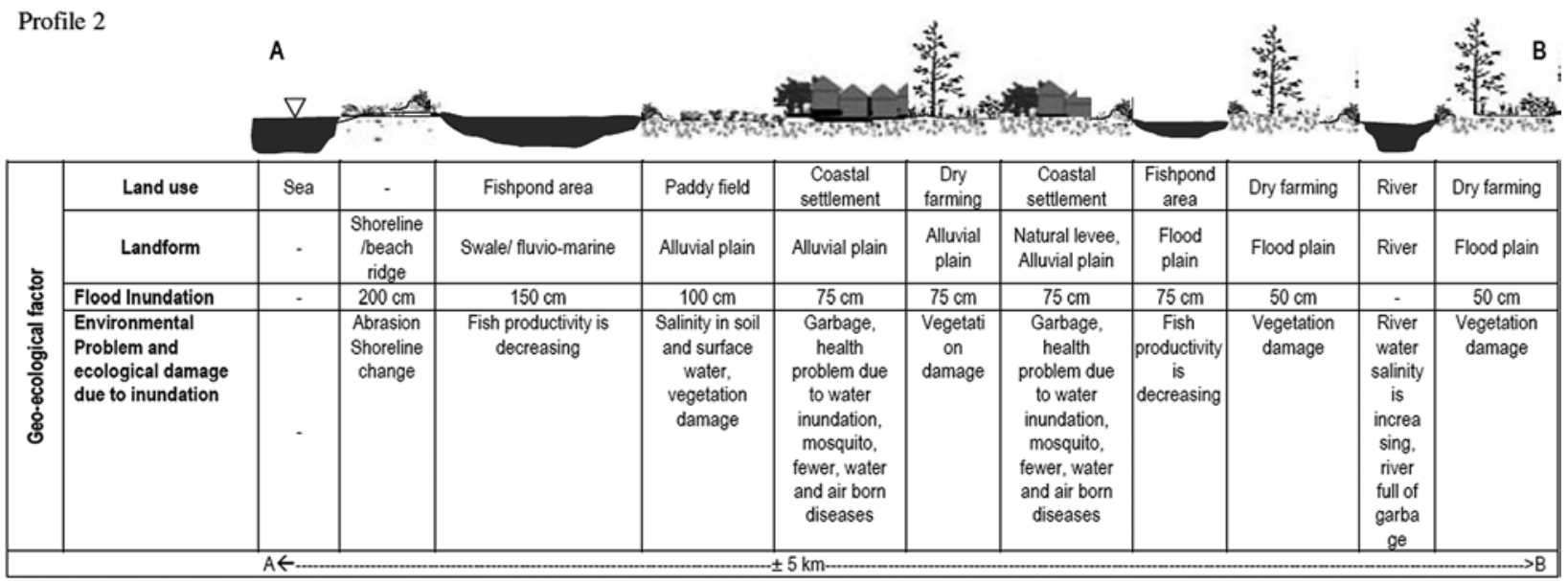

Fig. $8.2^{\text {nd }}$ cross profile.

in Figure 9). Significant damage of house structure in coastal settlement will also occur due to frequent inundation (Figure 10). Foundations of houses are badly damaged since they are inundated. Moreover, inundation will also accelerate dry farming destruction (Figure 11). Dry farming is the type of farming that does not require much water. When it is too wet or inundated, the crops will be damaged.

Coastal inundation impact in the third cross profile (Figure 12) is obviously the same as that found in the previous profile. Garbage and disposal waste directed to channel will be harmful to coastal settlement and crops since this channel flows surrounding settlement and crops areas (Figure 13).

Much more complicated problem due to coastal inundation can be shown in the fourth cross profile, (Figure 14) such as abrasion, land subsidence, abandon fishpond area and vegetation damage due to relatively high water of inundation. Coastal inundation not only can cause

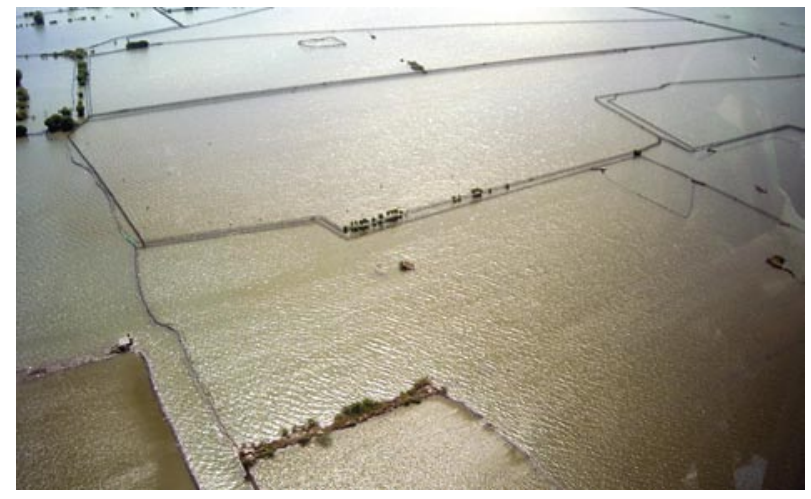

Fig. 9. Loss of fishpond area (Photo courtesy: Helmi) decrease in fish production but also can lead to the abandonment of fishpond area. By this condition, fish demand cannot be fulfilled anymore from this area. Water inundation in dry farming and paddy field can decrease productivity of paddy rice and crops harvest. The decline of

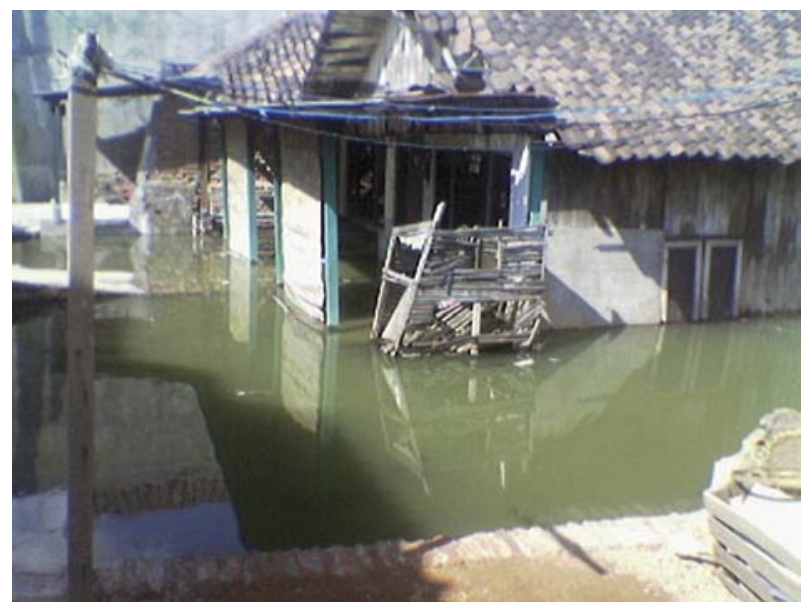

Fig. 10. House damage due to tidal inundation.

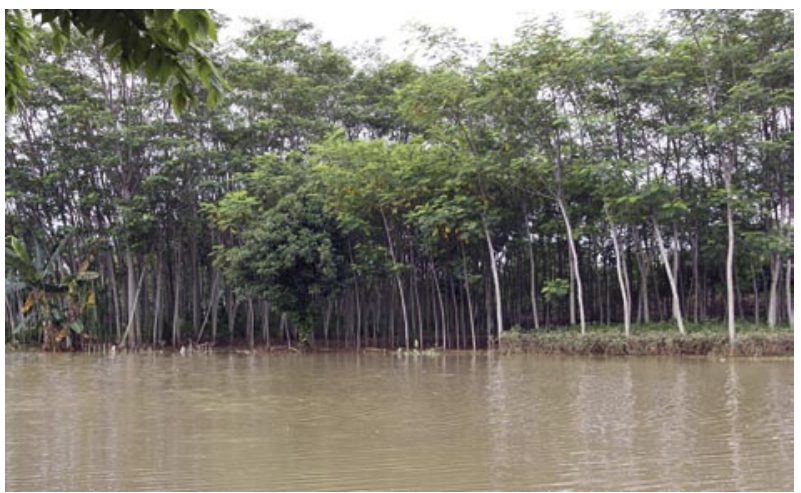

Fig. 11. Flooded dry farming. 
Profile 3

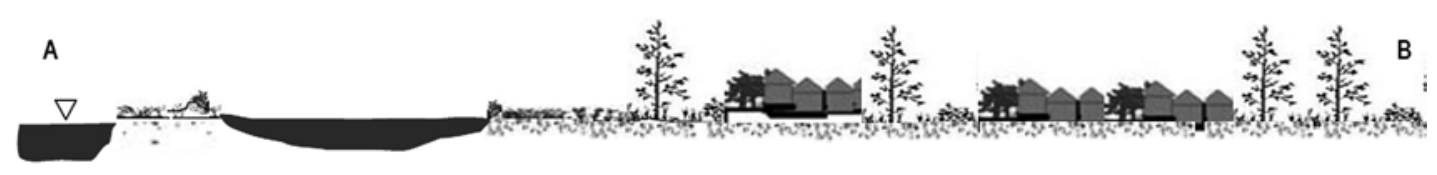

\begin{tabular}{|c|c|c|c|c|c|c|c|c|c|c|}
\hline \multirow[b]{4}{*}{ 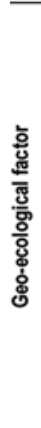 } & Land use & Sea & - & Fishpond area & Paddy field & $\begin{array}{l}\text { Dry } \\
\text { farming }\end{array}$ & $\begin{array}{c}\text { Coastal } \\
\text { settlement }\end{array}$ & Dry farming & Coastal settlement & Dry farming \\
\hline & Landform & - & $\begin{array}{c}\text { Shoreline } \\
\text { /beach } \\
\text { ridge }\end{array}$ & Swale/ fluvio-marine & Alluvial plain & $\begin{array}{c}\text { Alluvial } \\
\text { plain }\end{array}$ & Alluvial plain & $\begin{array}{c}\text { Alluvial } \\
\text { plain }\end{array}$ & Alluvial plain & Alluvial plain \\
\hline & Flood Inundation & - & $200 \mathrm{~cm}$ & $150 \mathrm{~cm}$ & $100 \mathrm{~cm}$ & $75 \mathrm{~cm}$ & $75 \mathrm{~cm}$ & $50 \mathrm{~cm}$ & $50 \mathrm{~cm}$ & $25 \mathrm{~cm}$ \\
\hline & $\begin{array}{l}\text { Environmental } \\
\text { Problem and } \\
\text { ecological } \\
\text { damage due to } \\
\text { inundation }\end{array}$ & - & $\begin{array}{c}\text { Abrasion } \\
\text { Shoreline } \\
\text { change }\end{array}$ & Fish productivity is decreasing & $\begin{array}{l}\text { Salinity in soil } \\
\text { and surface } \\
\text { water, } \\
\text { vegetation } \\
\text { damage }\end{array}$ & $\begin{array}{l}\text { Vegetati } \\
\text { on } \\
\text { damage }\end{array}$ & $\begin{array}{c}\text { Land } \\
\text { subsidence, } \\
\text { Garbage, } \\
\text { health } \\
\text { problem due } \\
\text { to water } \\
\text { inundation, } \\
\text { mosquito, } \\
\text { fewer, water } \\
\text { and air born } \\
\text { diseases }\end{array}$ & $\cdot$ & $\begin{array}{l}\text { Land subsidence, Water } \\
\text { pollution due to garbage } \\
\text { disposal }\end{array}$ & $\cdot$ \\
\hline
\end{tabular}

Fig. 12. $3 \mathrm{t}^{\mathrm{h}}$ cross profile.

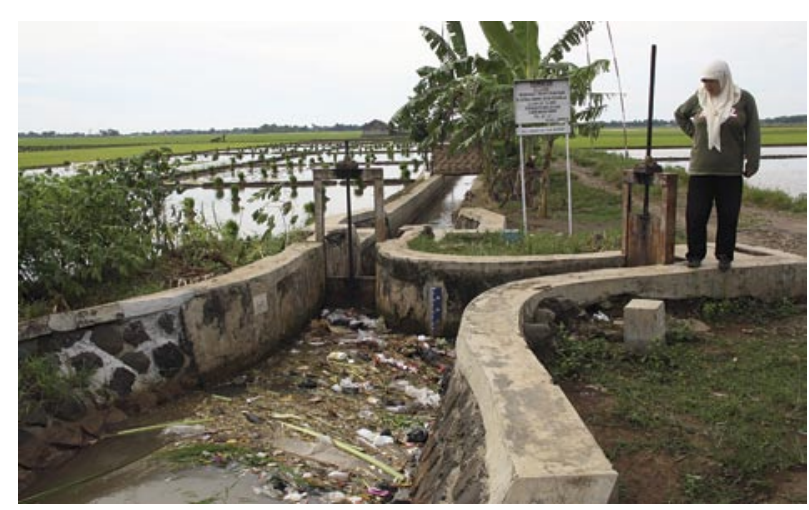

Fig. 13. Garbage and waste disposal in channel.

harvest production is not only in its quantity but also the quality. The quality of leaves and seed will decline, for instance, smaller size of tobacco leaves can negatively impact dried tobacco leaf production.

The water lens in coastal area can be disturbed by tidal behavior. One of the factors that will influence the manner of fresh groundwater in a beach is tidal cycle and range (Urish and McKenna, 2004). The fifth cross profile (Figure 15) reveals the example of the influence of tidal process on the groundwater condition. Flood tide will influence groundwater manner particularly in correlation with salt water component in flood tide. Preliminary assessment using electrical conductivity analysis has been done by Mining Office of which result suggesting the influence of coastal inundation to groundwater salinity in coastal area is shown in Table 1 . These monitoring wells were analyzed in 1995 and 2000. Three of these wells show various electrical conductivity with different distances from the closest harbor to coast line. Based on electrical conductivity analysis, it is clearly shown that groundwater surrounding this harbor was already saline in 2000. One well that has a distance of about 4.16 $\mathrm{Km}$ contained fresh water in 1995 and became saline in 2000. Influence of tidal inundation to

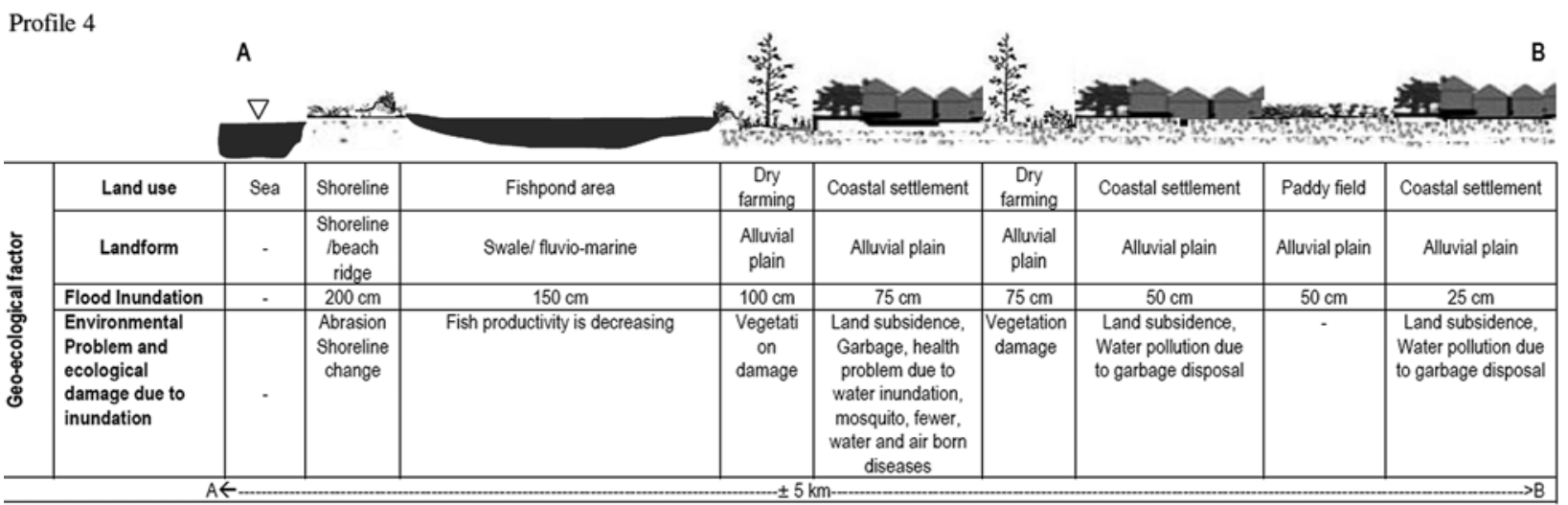

Fig. $14.4^{\text {th }}$ cross profile. 


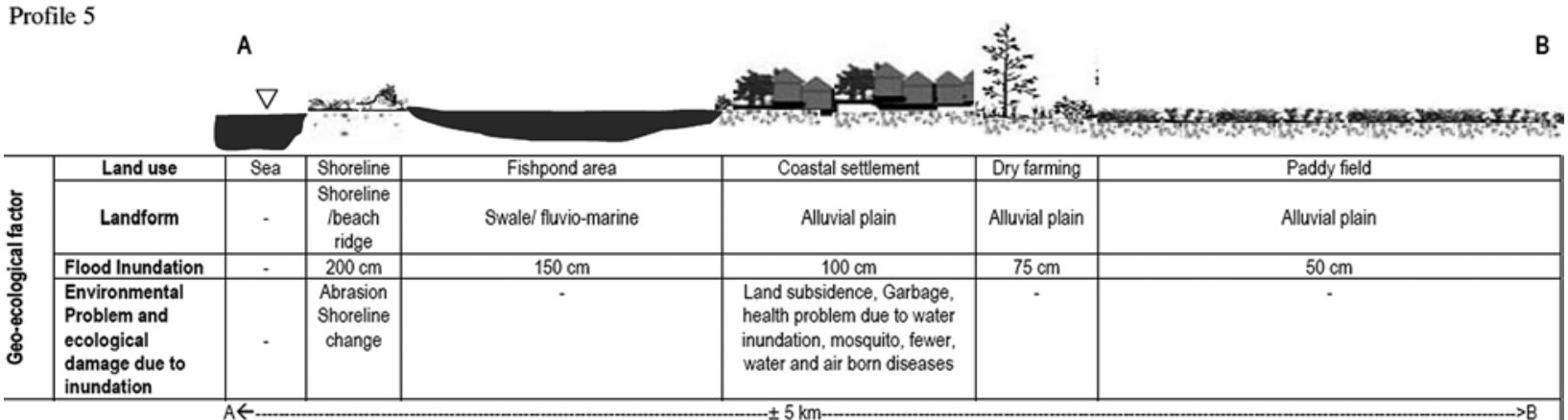

Fig. $15.5^{\text {th }}$ cross profile.

Tabel 1. Electrical conductivity in monitoring wells surrounding Tanjung Mas Harbor Year 1995 and 2000.

\begin{tabular}{|c|c|c|c|}
\hline \multirow[t]{2}{*}{$\mathrm{Nu}$} & \multirow{2}{*}{$\begin{array}{l}\text { Distant from } \\
\text { tanjung Mas } \\
\text { Harbor (Km) }\end{array}$} & \multicolumn{2}{|c|}{$\begin{array}{l}\text { Electrical conductivity (Micro- } \\
\text { mhos/cm) }\end{array}$} \\
\hline & & Year 1995 & Year 2000 \\
\hline 1 & 1.95 & 698 & 1090 \\
\hline 2 & 4.16 & 84 & 835 \\
\hline 3 & 4.34 & 1115 & 1564 \\
\hline
\end{tabular}

Source: Mining Office.
Tabel 2. Groundwater level condition in monitoring wells surrounding Tanjung Mas Harbor Year 1995 and 2000.

\begin{tabular}{|c|c|c|c|}
\hline \multirow{2}{*}{ Nu } & $\begin{array}{c}\text { Distant from } \\
\text { Tanjung Mas } \\
\text { Harbor (Km) }\end{array}$ & \multicolumn{2}{|c|}{$\begin{array}{c}\text { Groundwater table (metres } \\
\text { with local surface reference) }\end{array}$} \\
\cline { 3 - 4 } & Year 1995 & Year 2000 \\
\hline 1 & 0.37 & -19.94 & -23 \\
\hline 2 & 2.07 & -12 & -14 \\
\hline 3 & 3.48 & -24.6 & -28 \\
\hline
\end{tabular}

Source: Mining Office.

Profile 6

\begin{tabular}{|c|c|c|c|c|c|c|c|c|c|c|c|}
\hline \multicolumn{12}{|c|}{ Profile 6} \\
\hline \multirow[b]{4}{*}{ 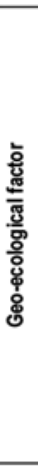 } & Land use & Sea & Shoreline & Fishpond area & Paddy field & $\begin{array}{c}\text { Coastal } \\
\text { settlement }\end{array}$ & River & $\begin{array}{c}\begin{array}{c}\text { Coastal } \\
\text { settlement }\end{array} \\
\text { sela }\end{array}$ & Paddy field & Dry farming & Paddy field \\
\hline & Landform & - & $\begin{array}{l}\text { Shoreline } \\
\text { /beach } \\
\text { ridge }\end{array}$ & $\begin{array}{l}\text { Swale/ fluvio- } \\
\text { marine }\end{array}$ & Alluvial plain & $\begin{array}{c}\text { Alluvial } \\
\text { plain I } \\
\text { natural } \\
\text { levee }\end{array}$ & River & $\begin{array}{l}\text { Alluvial plain / } \\
\text { natural levee }\end{array}$ & Alluvial plain & Alluvial plain & Alluvial plain \\
\hline & Flood Inundation & - & $150 \mathrm{~cm}$ & $150 \mathrm{~cm}$ & $100 \mathrm{~cm}$ & $75 \mathrm{~cm}$ & $\cdot$ & $50 \mathrm{~cm}$ & $50 \mathrm{~cm}$ & $25 \mathrm{~cm}$ & - \\
\hline & $\begin{array}{l}\text { Environmental } \\
\text { Problem and } \\
\text { ecological damage } \\
\text { due to inundation }\end{array}$ & - & - & $\cdot$ & $\begin{array}{l}\text { Salinity in soil } \\
\text { and surface } \\
\text { water, } \\
\text { vegetation } \\
\text { damage }\end{array}$ & $\begin{array}{c}\text { Garbage, } \\
\text { health } \\
\text { problem } \\
\text { due to } \\
\text { water } \\
\text { inundation, } \\
\text { mosquito, } \\
\text { fewer, } \\
\text { water and } \\
\text { air born } \\
\text { diseases }\end{array}$ & $\begin{array}{c}\text { River } \\
\text { water } \\
\text { salinity } \\
\text { is } \\
\text { increasi } \\
\text { ng, river } \\
\text { full of } \\
\text { garbage }\end{array}$ & $\begin{array}{c}\text { Water } \\
\text { pollution due } \\
\text { to garbage } \\
\text { disposal }\end{array}$ & & & \\
\hline & & & & & & $= \pm 5 \mathrm{~km}$ & & & & $\ldots$ & 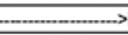 \\
\hline
\end{tabular}

Fig. 16. $6^{\text {th }}$ cross profile.

groundwater discharge can be measured by examining groundwater level condition. Different levels of groundwater surrounding Tanjung Mas Harbor can be shown in Table 2. From Table 2, it is indicated that groundwater discharge to the coast decreased during 1995-2000 within these three monitoring wells.

The direct impact of coastal inundation on coastal ecosystem is the disturbance of mangrove ecosystem. The sixth cross profile (Figure 16) shows the environmental problem related to vegetation damage due to tidal inundation and

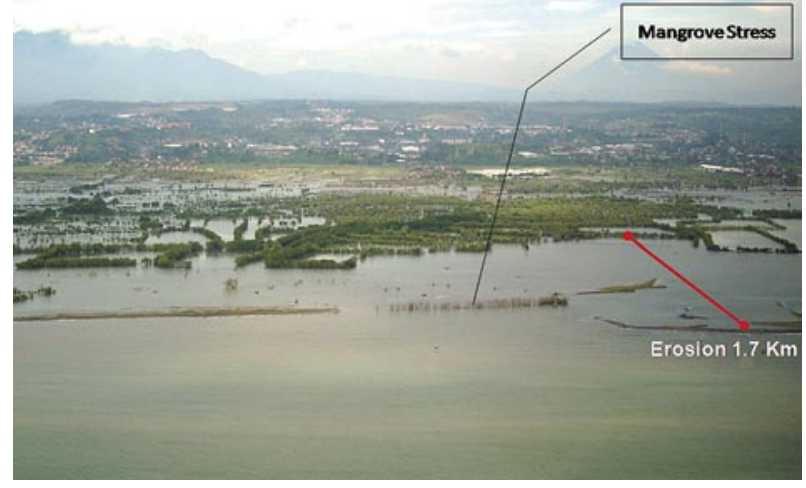

Fig. 17. Mangrove damage due to tidal inundation and abrasion (Photo courtesy: Helmi) 


\begin{tabular}{|c|c|c|c|c|c|c|c|c|c|}
\hline \multirow{4}{*}{ 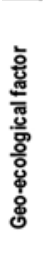 } & Land use & Sea & Shoreline & Fishpond area & $\begin{array}{l}\text { Riverl } \\
\text { chanal }\end{array}$ & Fishpond area & Paddy field & $\begin{array}{c}\text { Coastal } \\
\text { settlement }\end{array}$ & Paddy field \\
\hline & Landform & $\cdot$ & $\begin{array}{c}\text { Shoreline } \\
\text { /beach } \\
\text { ridge }\end{array}$ & Swale/ fluvio-marine & River & back swamp & Alluvial plain & $\begin{array}{l}\text { Alluvial } \\
\text { plain }\end{array}$ & Alluvial plain \\
\hline & Flood Inundation & $\cdot$ & $200 \mathrm{~cm}$ & $150 \mathrm{~cm}$ & $\cdot$ & $100 \mathrm{~cm}$ & $75 \mathrm{~cm}$ & $50 \mathrm{~cm}$ & $25 \mathrm{~cm}$ \\
\hline & $\begin{array}{l}\text { Environmental } \\
\text { Problem and } \\
\text { ecological damage } \\
\text { due to inundation }\end{array}$ & $\cdot$ & $\begin{array}{c}\text { Abrasion } \\
\text { Shoreline } \\
\text { change }\end{array}$ & Fish productivity is decreasing & & $\begin{array}{l}\text { Fish productivity is } \\
\text { decreasing }\end{array}$ & Water pollution & $\begin{array}{l}\text { Water } \\
\text { pollution } \\
\text { due to } \\
\text { garbage } \\
\text { disposal }\end{array}$ & $\cdot$ \\
\hline
\end{tabular}

Fig. $18.7^{\text {th }}$ cross profile.

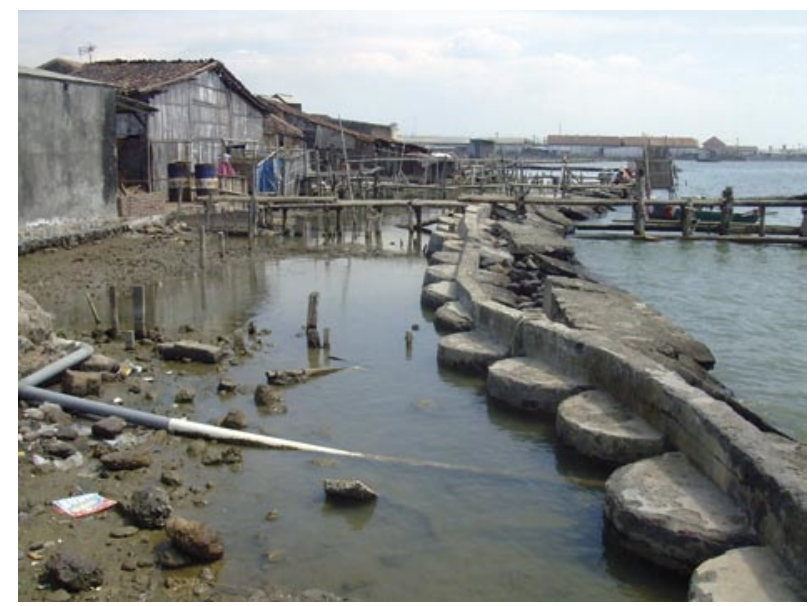

Fig. 19. Damaged infrastructure due to erosion and abrasion.

abrasion. Vegetation damage in the sixth Profile occurred not only in crops production but also in mangrove vegetation. Moreover, mangrove as a coastal protector, can be damaged because of coastal inundation and abrasion. This ecosystem is actually the primary barrier in this coastal area (Figure 17). As an example, the number of mangrove area in Semarang coastal area during 1999-2005 declined about 14, 3 Hectares.
Abrasion and erosion conditions in coastal area due to inundation can be seen in the seventh cross profile (Figure 18). The rate of abrasion and erosion will speed up due to continuous coastal inundation. This condition causes damage of houses and infrastructure in this area (Figure 19). To provide an example for this is the erosion rate in 1999-2005 in a spot of Semarang coastal areas, located in Genuk District which reached 215.2 Hectares (Irwani et al. 2010).

The last cross profile (Figure 20) gives an example of the water pollution as an environmental problem (Figure 21). Intensive water pollution particularly surface water pollution occurs in this area due to the erosion process taking place on the upper part area. This pollution can threaten ecosystem lying below this water.

\section{Impact of inundation on agricultural landuse}

Satellite images technology, such as landsat etm and ikonos would be very useful for land use assessment and mapping. Multi sources images can help to evaluate the compositional changes of land use between years. Agricultural land use

Profile 8

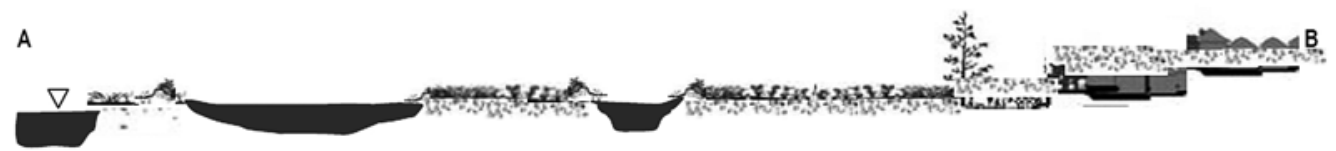

\begin{tabular}{|c|c|c|c|c|c|c|c|c|c|}
\hline \multirow{4}{*}{ 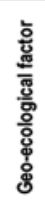 } & Land use & $\begin{array}{l}\text { Java } \\
\text { sea }\end{array}$ & Shoreline & Fishpond area & Paddy field & River & Paddy field & Dry farming & Coastal settlement \\
\hline & Landform & Sea & $\begin{array}{c}\text { Shoreline } \\
\text { /beach } \\
\text { ridge }\end{array}$ & Swale & Alluvial plain & $\begin{array}{l}\text { Water } \\
\text { course }\end{array}$ & Alluvial plain & $\begin{array}{l}\text { Alluvial } \\
\text { plain }\end{array}$ & $\begin{array}{c}\text { Denudational footslope/ } \\
\text { colluviums }\end{array}$ \\
\hline & Flood Inundation & Sea & $200 \mathrm{~cm}$ & $150 \mathrm{~cm}$ & $100 \mathrm{~cm}$ & - & $50 \mathrm{~cm}$ & $25 \mathrm{~cm}$ & - \\
\hline & $\begin{array}{l}\text { Environmental Problem/ } \\
\text { Degradation }\end{array}$ & Sea & $\begin{array}{c}\text { Abrasion } \\
\text { Shoreline } \\
\text { change }\end{array}$ & $\begin{array}{l}\text { Fish productivity is } \\
\text { decreasing }\end{array}$ & $\cdot$ & & Water pollution & $\cdot$ & $\cdot$ \\
\hline
\end{tabular}

Fig. 20. $8^{\text {th }}$ cross profile. 


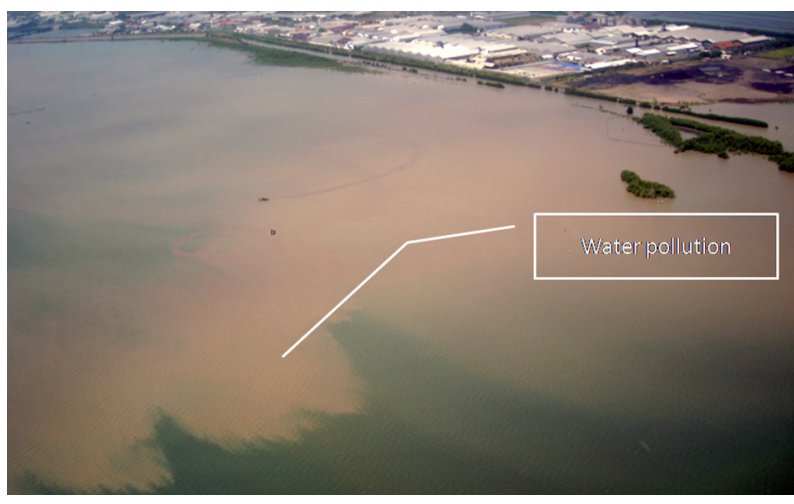

Fig. 21. Surface water pollution (Photo courtesy: Helmi).

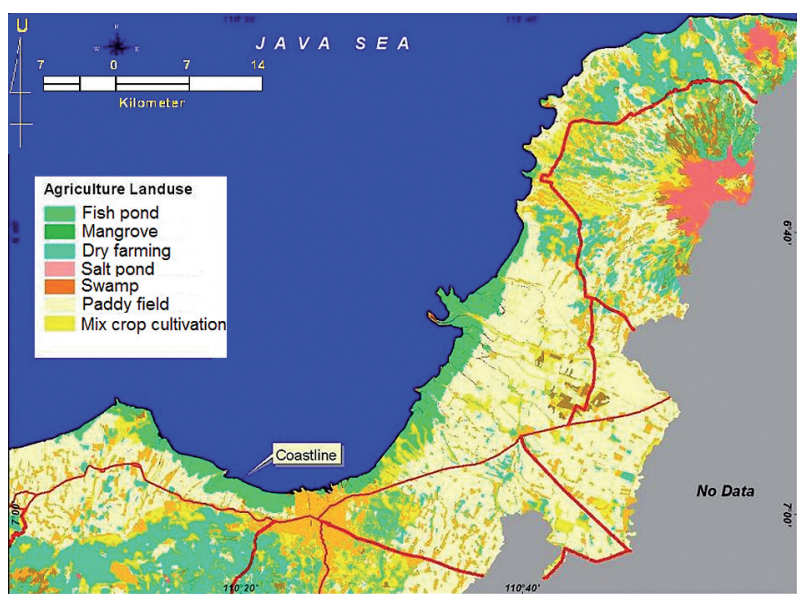

Fig. 22. Agricultural Landuse map of the study area.

map in the study area has been generated using interpretation of satellite images on the area of Kendal, Demak, and Jepara. Moreover, additional information of the landuse map has been compiled from the previous research of Marfai \& King (2008a) for the Semarang coastal area and. Land use map of the study area is shown in Figure 22. Overlaying the inundated areas and agricultural landuse map allows an assessment of the impact of the inundation. Table 3 and 4 reveal the agricultural area affected by inundation of the $100 \mathrm{~cm}$ depth and $150 \mathrm{~cm}$ depth respectively.

On the model of $100 \mathrm{~cm}$ depth of inundation, fishpond area, paddy field and dry framing areas are the most vulnerable areas. In total, the inundation will spread up to 15 thousand Hectares. The inundation will obviously cause damage to the vegetation, soil and environment. For the high scenario of $150 \mathrm{~cm}$, the total inundation will be more than 16 thousand hectares spreading from Kendal, Semarang, Demak and Jepara coastal area. Again, the inundation in fishpond, paddy
Table 3. Agricultural land use affected by coastal inundation with scenario $100 \mathrm{~cm}$ depth of inundation.

\begin{tabular}{|c|l|r|}
\hline No & Type of agriculture land use & Area (Ha) \\
\hline 1 & Dry farming & 128 \\
\hline 2 & Salt pond & 5 \\
\hline 3 & Fishpond & 14,444 \\
\hline 4 & Paddy field & 360 \\
\hline 5 & Swamp & 124 \\
\hline 6 & Mix crop cultivation & 42 \\
\hline 7 & Mangrove & 104 \\
\hline & Total & 15,208 \\
\hline
\end{tabular}

Table 4. Agricultural land use affected by coastal inundation with scenario $150 \mathrm{~cm}$ depth of inundation.

\begin{tabular}{|c|l|r|}
\hline No & Type of agriculture land use & Area (Ha) \\
\hline 1 & Dry farming & 530 \\
\hline 2 & Salt pond & 6 \\
\hline 3 & Fishpond & 14,588 \\
\hline 4 & Paddy field & 1,183 \\
\hline 5 & Swamp & 157 \\
\hline 6 & Mix crop cultivation & 103 \\
\hline 7 & Mangrove & 120 \\
\hline & Total & 16,687 \\
\hline
\end{tabular}

field and dry farming will increase significantly up to more than 14 thousand $\mathrm{Ha}, 1$ thousand $\mathrm{Ha}$, and 530 Hectare respectively. These valuable information and data are considered as important data for mitigation action and risk reduction program along the coastal area of Central Java.

As mentioned before, this research utilized the tools in GIS technique. A superimposed technique between agricultural land use map and inundation model provides an advantage to monitor the impact of inundation in spatial context. By using large scale of spatial data input, the damaged agricultural area can be identified effectively. Given the ability of the GIS technology for monitoring the impact of the coastal inundation, for the next future research, the assessment of the risk and the calculation of damage in term of economic losses can be also done by calculating the loss of productivity based on the market today values on that area.

\section{Conclusion and Remark}

Considering the importance of natural resources and economic asset on the coastal area, the technical model using GIS for coastal inun- 
dation mapping under the different scenarios of the depth of inundation is considered as the important task to support the action plan of risk reduction program. Using DEM data and utilizing raster based GIS technology, the inundation map can be generated and the spatial impact of inundation can be observed.

Cross section profilling done on this research is regarded as an effective measurement technique, with regards to the time and technical constrains. However, several things remain to be discussed on future research, i.e., issue related to number of the cross section to be made, distance and route of the profilling, and the integration between the (micro) landform unit and landuse unit as geo-ecological approach used as based of the field observation.

By having the figure of the impact of the inundation on each agricultural unit, the risk assessment and damage could be calculated. It is therefore suggested that in the future research, the number of the productivity per class of agricultural unit and recent market value of each productivity should also be taken into account.

\section{Acknowledgement}

This research was supported by the International Foundation for Science, Stockholm, Sweden, through a grant to Muh Aris Marfai (A/4607-1). The author expresses his gratitude to Mr. Fajar Yulianto (Remote Sensing Application and Technology Development Center, Indonesian National Institute of Aeronautics and Space/LAPAN, Jakarta, Indonesia) for providing digital data and helping cross-section design, to Ms. Novi Rahmawati (M.Sc program in Planning and Management of Coastal Area and Watershed, Fac. Of Geography, Gadjah Mada Universtiy) for helping technical data collection, Mr. M. Helmi (Faculty of Fisheries and Marine Science, Diponegoro University) for his permission to use his field-photos collection, for intensive discussion and valuable knowledge related to coastal dynamic in Semarang City, and to the reviewers for their helpful advice.

\section{Reference}

Bryan B., Harvey N., Belerio T. \& Bourman B., 2001. Distributed Process Modeling for Regional Assessment of Coastal Vulnerability to Sea Level Rise. Environ Model Assess 6: 57-65.

Gatot I.S., Duchesne J., Forest F., Perez P., Cudennec C., PraSETYO T. \& KARAMA S., 2001. Rainfall-runoff harvesting for controlling erosion and sustaining upland agriculture development. In: D.E. Stott, R.H. Mohtar, G.C. Steinhardt (eds.), Sustaining the global farm. Selected papers from the 10th international soil conservation organization meeting held, 24-29 May 1999 at Purdue University and the USDA-ARS National Soil Erosion Research Laboratory: 434-441.

ILWIS, 2000. Integrated Land and Water Information System, Geographic Information System, Version 3.1. International Institute for Geo-Information and Earth Observation, ITC, Enschede.

Irwani, Pribadi R. \& Helmi M., 2010. Studi Erosi Pesisir Kota Semarang. Jurusan Ilmu Kelautan, FPIK UNDIP presented at Presented for Indonesian Delta Forum, Bakosurtanal, Semarang 21-22 October 2010.

Johannsen C.J., Engel B.A. \& PANTAleoni E., 2007. Identifying agricultural flood damage using Landsat imagery. Precision Agric. 8: 27-36.

KOBAYASHI H., 2003. Vulnerability assessment and adaptation strategy to sea-level rise in Indonesian coastal urban area. National Institute for Land and Infrastructure Management, Ministry of Land, Infrastructure and Transport, Japan.

Kresch D.L., Mastin M.C. \& Olsen T.D., 2002. Fifty-year floodinundation maps for Olanchito, Honduras. US Geological Survey.

KumAR DiNEsh P.K., 2006. Potential vulnerability implications of sea level rise for the coastal zones of Chocin, southwest coast of India. Environmental Monitoring and Assessment 123: 333-344.

Lebedeva I.P., Kocharyan A.G. \& Istomina M.N., 2005. Floods: genesis, socioeconomic and environmental impacts. $\mathrm{Wa}$ ter Resources 32(4): 349-358.

MARFAI M.A., 2004. Tidal flood hazard assessment: modelling in raster GIS, case in western part of Semarang coastal area. Indonesian Journal of Geography 36(1): 25-38.

MARfaI M.A., 2005. GIS Modelling Exercise Using ILWIS Software for Landslide Assessment. Journal of Scientific Development and Environmental Research 4, 1-2: 24-34.

Marfai M.A., King L., 2007. Monitoring land subsidence in Semarang, Indonesia. Environmental Geology 53: 651-659.

Marfai M.A. \& KING L., 2008a. Coastal flood management in Semarang. Environmental Geology 55: 1507-1518.

Marfai M.A. \& KING L., 2008b. Tidal inundation mapping under enhanced land subsidence in Semarang, Central Java Indonesia. Natural Hazards 44: 93-109.

Marfai M.A. \& KING L., 2008c. Potential vulnerability implication of coastal inundation due to sea level rise for the costal zone of Semarang City, Indonesia. Environmental Geology 54(6): 1235-1245.

Marfai M.A., Almohammad H., Dey S., Susanto B. \& King L., 2008. Coastal dynamic and shoreline mapping: multisources spatial data analysis in Semarang Indonesia. Environmental Monitoring and Assessment 142: 297-308.

Maulina N., 2010. Shoreline Change Analysis and Prediction; an Application of Remote Sensing and GIS. M.Sc. thesis, Geography Faculty, Gadjah Mada University, Yogyakarta, Indonesia. 
Michele C., 1999. On the integrated modeling of coastal changes. Journal of Coastal Conservation 5: 113-124.

Pasternack G.B., Hilgartner W.B. \& Brush G.S., 2000. Biogeomorphology of an upper Chesapeake Bay river-mouth tidal freshwater marsh. Wetlands 20(3): 520-537.

Pinem F., 2002. The Use of Aerial Photographs for Susceptibility Mapping of Flood Hazard in Kali Garang, Semarang Central Java (in Indonesian). Undergraduate Thesis, Geography Faculty, Gadjah Mada University, Yogyakarta, Indonesia.

PWD (Public Works Department of Semarang), 2000. Semarang Urban Drainage Master Plan Project. Public Works Department, Semarang, Indonesia.

Schladow S.G., Fleenor W.E. \& Hammersmark C.T., 2005 Simulation of food impact and habitat extent for a tidal freshwater marsh restoration. Ecological Engineering 25: 137-152.

Smith K. \& Ward R., 1998. Floods: Physical Processes and Human Impacts. John Wiley and Sons, Chichester, USA.
Sudaryatno S., 2000. Remote Sensing and GIS for Estimation of Peak Discharge at garang River, Semarang Central java (in Indonesian). Master Thesis, Geography Faculty, Gadjah Mada University, Indonesia.

URISH D.W. \& McKenNA T.E., 2004. Tidal Effects on Groundwater Discharge Through a Sandy marine Beach. Ground Water - Oceans Issue 42, 7: 971-982.

Ward P.J., Marfai M.A., Yulianto F., Hizbaron D.R. \& Aerts J.C.J.H., 2011. Coastal Inundation and Damage Exposure Estimation: A Case Study for Jakarta. Natural Hazards 56: 899-916.

Yusup Y., 1999. Study of Flood Vulnerability and Hazard in Semarang Area (in Indonesian). Undergraduate Thesis, Geography Faculty, Gadjah Mada University, Yogyakarta, Indonesia.

Thumerer T., Jones A.P. \& Brown D. 2000. A GIS based coastal management system for climate change associated flood risk assessment on the east coast of England. Int. J. Geogr. Inf. Sci. 14(3): 265-281. 